\title{
Ion Chromatographic Determination of Common Inorganic Anions in Tea Samples
}

\author{
Mustafa CITTAN ${ }^{1 *}$ \\ ${ }^{1}$ Department of Chemistry, Faculty of Science and Letters, Manisa Celal Bayar University, 45140, \\ Manisa, Turkey
}

Geliş / Received: 15/02/2021, Kabul / Accepted: 01/03/2021

\begin{abstract}
A simple, rapid, and accurate technique based on ion chromatography coupled with a suppressed conductivity detector was described to determine the inorganic anions - fluoride, chloride, nitrite, bromide, nitrate, phosphate, and sulphate in tea bag samples. A Dionex IonPac AS9-HC $4 \times 250 \mathrm{~mm}$ analytical column with a Dionex IonPac AG9-HC $4 \times 50 \mathrm{~mm}$ guard column was used for the chromatographic separation of the analytes. The eluent was $12 \mathrm{mM} \mathrm{KOH}$ and the limit of quantification for the inorganic anions were in the range 0.02 $0.20 \mathrm{mg} \mathrm{L}^{-1}$. Tea infusions were prepared traditionally by pouring the tea bags with $200 \mathrm{~mL}$ of boiling ultrapure water. Influence of the brewing time on the extraction of inorganic anions from the tea bags was examined and optimum brewing time was determined as $6 \mathrm{~min}$ according to the results obtained. Finally, the ion chromatographic technique was applied to analyze the inorganic anions in some black, green, and white tea bag samples and five anions were determined quantitatively. The nitrite and bromide amount in all the samples were well below the quantification limit of the method.
\end{abstract}

Keywords: Ion chromatography, inorganic anions, black tea, green tea, white tea

Yaygın İnorganik Anyonların Çay Örneklerinde İyon Kromatografik Tayini

$\ddot{O} z$

Bu çalışmada, poşet çaylarda bulunan inorganik anyonları - florür, klorür, nitrit, bromür, nitrat, fosfat ve sülfat belirlemek için, iletkenlik detektörü ile eşleştirilmiş iyon kromatografisine dayalı basit, hızlı ve doğru bir teknik tanımlanmıştır. Analitlerin kromatografik ayrılması, Dionex IonPac AG9-HC 4×50 mm ön kolonu ile birleştirilmiş, Dionex IonPac AS9-HC 4x250 mm analitik kolon kullanılarak gerçekleştirilmiştir. Elüent olarak $12 \mathrm{mM} \mathrm{KOH}$ çözeltisi kullanılmıştır. İnorganik anyonlar için tayin limitleri, $0.02-0.20 \mathrm{mg} \mathrm{L}^{-1}$ aralığında belirlenmiştir. Çay infüzyonları geleneksel olarak poşet çayların $200 \mathrm{~mL}$ hacimli kaynar ultra saf su ile demlenmesi yoluyla hazırlanmıştır. Söz konusu anyonların ekstraksiyonuna demleme süresinin etkisi incelenmiş ve elde edilen sonuçlara göre optimum demleme süresi 6 dakika olarak belirlenmiştir. Son olarak tarif edilen kromatografik yöntem bazı siyah, yeşil ve beyaz poşet çay örneklerindeki inorganik anyonların analizleri için uygulanmış ve beş adet anyon numunelerde nicel olarak belirlenmiştir. Tüm örneklerdeki nitrit ve bromür miktarları ise yöntemin tayin limitlerinin oldukça altında tespit edilmiştir.

Anahtar Kelimeler: İyon kromatografi, inorganik anyonlar, siyah çay, yeşil çay, beyaz çay

\section{Introduction}

Tea is a caffeine-containing non-alcoholic beverage and gaining extra popularity as an important "health drink" (Mondal et al.,
2004). Its consumption is very popular in the world, second only to water. Especially tea bags are frequently used to prepare the beverage practically in our country. Tea bags are simply brewed in approximately $200 \mathrm{~mL}$ 
of boiling water for 2-6 minutes in this preparation technique.

Black, green, and white teas are produced from the leaves of Camellia sinensis. The differences between them are due to the processing technique of the leaves during harvesting and manufacturing (Mincă et al., 2013). The chemical composition of tea is complex (Michalski, 2006; Yashin et al., 2015). The major chemical compounds present in tea are given in Table 1.

Table 1. Chemical composition of tea

\begin{tabular}{|c|c|}
\hline Group & Compounds \\
\hline Polyphenols & $\begin{array}{l}\text { Catechins, flavanols, } \\
\text { theaflavins, theagallins }\end{array}$ \\
\hline Amino acids & $\begin{array}{l}\text { Asparagine, alanine, serine, } \\
\text { proline, histidine, theanine, } \\
\text { phenylalanine }\end{array}$ \\
\hline Organic acids & $\begin{array}{l}\text { Acetic acid, citric acid, malic } \\
\text { acid, succinic acid }\end{array}$ \\
\hline Enzymes & Polyphenol oxidase, peroxidase \\
\hline Pigments & Chlorophyll, carotenoids \\
\hline Carbohydrates & Glucose, fructose, saccharose \\
\hline Alkaloids & $\begin{array}{l}\text { Caffeine, theophylline, } \\
\text { theobromine }\end{array}$ \\
\hline Vitamins & $\mathrm{C}$, tocopherols, riboflavin \\
\hline Metals & $\mathrm{Al}, \mathrm{Cu}, \mathrm{Fe}, \mathrm{Ni}, \mathrm{Zn}$ \\
\hline Cations & $\mathrm{Na}^{+}, \mathrm{K}^{+}, \mathrm{Ca}^{2+}, \mathrm{Mg}^{2+}, \mathrm{Al}^{3+}$ \\
\hline Inorganic anions & $\mathrm{F}^{-}, \mathrm{Cl}^{-}, \mathrm{NO}_{3}{ }^{-}, \mathrm{PO}_{4}{ }^{3-}, \mathrm{SO}_{4}{ }^{2-}$ \\
\hline
\end{tabular}

The toxicity level of inorganic anions is vital for human and environmental health. For example, fluoride is a significant micronutrient in low concentrations, and become toxic in high concentrations. Excessive fluoride consumption induces symptoms of acute and chronic fluoride toxicity (fluorosis) (Jagadish and Shanmugaselvan, 2018). Therefore, it becomes very important to clarify the amount of fluoride accumulation in tea plants (Ma et al., 2002). Chloride is the key anion in the extracellular fluid, and it is responsible for muscle irritability. Phosphorus compounds carry, store, and release energy and assist numerous enzymes and vitamins in extracting energy from nutrients. Nitrites and nitrates induce paralysation of the vasomotor centre, causing vasodilatation of small calibre vessels associated with hypotension and collapse (Mincă et al., 2013). Therefore, it is very important to monitor the inorganic anion contents in tea samples to maintain product quality.

Ion chromatography (IC) method is being widely used in food analysis for the simultaneous determination of many anions, mainly at trace concentration levels. There are several works on the quantitative analysis of some anions in tea infusions (Alcázar et al., 2003; Balcerzak and Janiszewska, 2015; Ding et al., 1997; Kumar et al., 2008; Michalski, 2006; Minca et al., 2015).

As a result of the importance of the quantification of inorganic anions in tea samples, nitrite, nitrate, phosphate, sulphate, chloride, fluoride, and bromide contents of the tea infusions prepared by using commercially available black, green and white tea bags were determined simultaneously by ion chromatographic technique in present study.

\section{Material and Methods}

\subsection{Reagents}

All reagents were of analytical reagent grade. Millipore Elix 5 Water Purification System was used to obtain ultra-pure water. Standard solutions of nitrite, nitrate, phosphate, sulphate, chloride, fluoride, and bromide at $1000 \mathrm{mg} \mathrm{L}^{-1}$ were purchased from Merck (Darmstadt, Germany). Potassium hydroxide was obtained from Sigma-Aldrich (St. Louis, MO, USA). Calibration solutions were prepared freshly by diluting the stock solutions with ultra-pure water. 


\subsection{Apparatus}

Ion chromatographic analyses were conducted by using Dionex ICS-5000 system coupled with a Dionex ASRS $3004 \mathrm{~mm}$ suppressed conductivity detector. Millipore Elix 5 Water Purification System was used to produce ultra-pure water.

\subsection{Sample collection}

Three brands of black tea bags, three brands of green tea bags, and two brands of white tea bags were purchased from local markets in Manisa, Turkey.

\subsection{Sample preparation}

The tea bags (one bag contains between 1.2 and $2.0 \mathrm{~g}$ of tea) were poured traditionally with $200 \mathrm{~mL}$ of boiling ultra-pure water and allowed to infuse for $6 \mathrm{~min}$ (optimum time detected in the study). The infusions were then cooled to room temperature and filtered through $0.45 \mu \mathrm{M}$ pore size, nylon syringe filter (Millipore) prior to analysis.

\subsection{Ion chromatography method}

The specifications of the ion chromatographic technique followed were presented in Table 2.

Table 2. The specifications of the ion chromatographic method

\begin{tabular}{|c|c|}
\hline Parameter & \\
\hline Guard column & $\begin{array}{l}\text { Dionex IonPac AG9-HC } \\
4 \times 50 \mathrm{~mm}\end{array}$ \\
\hline Analytical column & $\begin{array}{l}\text { Dionex IonPac AS9-HC } \\
4 \times 250 \mathrm{~mm}\end{array}$ \\
\hline Eluent & $12 \mathrm{mM} \mathrm{KOH}$ \\
\hline Flow rate & $1 \mathrm{~mL} \min ^{-1}$ \\
\hline Injection volume & $20 \mu \mathrm{L}$ \\
\hline Column temperature & $30^{\circ} \mathrm{C}$ \\
\hline Detection & Conductivity \\
\hline
\end{tabular}

\section{Results and Discussion}

\subsection{Linearity, sensitivity, and selectivity}

Sequential standard solutions of inorganic anions were analyzed by IC, respectively. All calibration standards were prepared by diluting the standard solutions of inorganic anions with ultra-pure water just before use. The correlation coefficients $\left(R^{2}\right)$ of the calibration equations were higher than 0.9988 for all anions as shown in Figure 1.
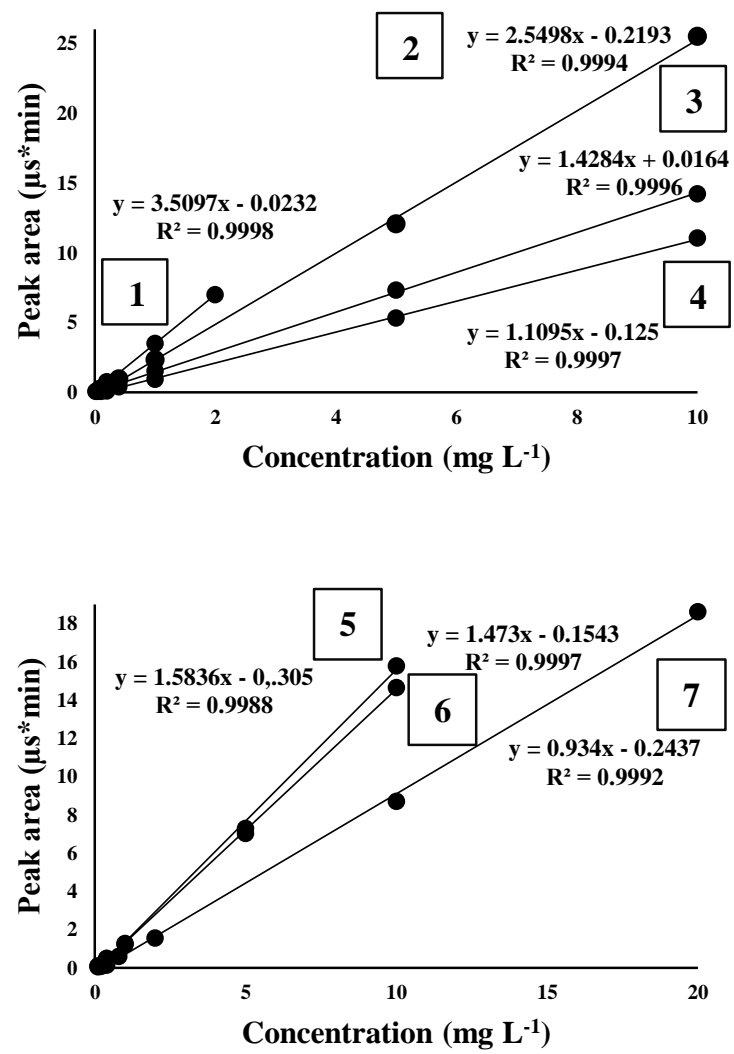

Figure 1. Calibration graphs of the inorganic anions. 17 represent the calibration curves of fluoride, chloride, nitrite, bromide, sulphate, nitrate, and phosphate, respectively.

The limit of quantifications (LOQs) were calculated by using the formula $\mathrm{LOQ}=10 \mathrm{~S}_{\mathrm{a}} / \mathrm{b}$, where $S_{a}$ is the standard deviation of the analytical response and $\mathrm{b}$ is the slope of the calibration equation $(Q 2 B$ Validation of 
Analytical Procedures: Methodology | FDA, 1997). The linearity and the sensitivity properties were summarized in Table 3.

Although the tea infusions could contain some ionic compounds that respond to the conductivity detector such as anions of organic acids or other non-target anions, the

\begin{tabular}{lllll}
\multicolumn{6}{l}{ Table 3. Analytical features of the methodology } \\
\hline Analyte & $\mathrm{R}_{\mathrm{t}}(\mathrm{min})$ & LOQ $\left(\mathrm{mg} \mathrm{L}^{-1}\right)$ & Linear range $\left(\mathrm{mg} \mathrm{L}^{-1}\right)$ & R-squared \\
\hline Fluoride & 4.097 & 0.02 & LOQ-2.0 & 0.9998 \\
Chloride & 5.560 & 0.10 & LOQ -10 & 0.9994 \\
Nitrite & 6.470 & 0.10 & LOQ -10 & 0.9996 \\
Bromide & 7.514 & 0.10 & LOQ -10 & 0.9997 \\
Nitrate & 8.297 & 0.10 & LOQ -10 & 0.9997 \\
Phosphate & 13.110 & 0.20 & LOQ -20 & 0.9992 \\
Sulphate & 19.750 & 0.10 & LOQ -10 & 0.9988
\end{tabular}

$R_{t}$, retention time.

\subsection{Effect of brewing time}

In order to determine the change in the amount of inorganic anions in the infusions depending on the brewing time of the tea bags in boiling water, the amount of each anions in the extracts obtained by brewing a black tea bag sample for 2, 4, 6, and 8 minutes were determined. A graph was provided in Figure 2 indicating the total amount of inorganic anions determined versus brewing time of the tea bag. It was clear from the results that the total amount of anions in the tea infusions increased up to $6 \mathrm{~min}$ of brewing time. In addition, it remained nearly constant after 6 min. To this end, the infusion time was selected as $6 \mathrm{~min}$.

\subsection{Analysis of the tea samples}

Inorganic anions in three brands of black and green tea samples, and two brands of white tea samples were quantified using the calibration equations of the anions as shown in Figure 1. The results obtained for the content of the determined anions in the tea infusions that of Table 4. Contents of inorganic anions in tea samples selectivity of the analytical anion-exchange column was quite high. In other words, the selectivity of the analytical technique was provided by chromatographic separation of the anionic compounds. Therefore, there was no interference to the methodology with the determination of the target inorganic anions.

corresponding to dry mass $\left(\mathrm{mg} \mathrm{g}^{-1}\right)$, were listed in Table 4. In addition, representative chromatograms obtained for a calibration standard and a black tea bag infusion were given together in Figure 3. The chromatographic technique provides welldefined peaks for all seven inorganic anions of interest in approximately $20 \mathrm{~min}$. It was clear from the sample chromatograms obtained that the bromide and nitrite concentrations in the tea bag infusions were well below the quantification limits of the technique.

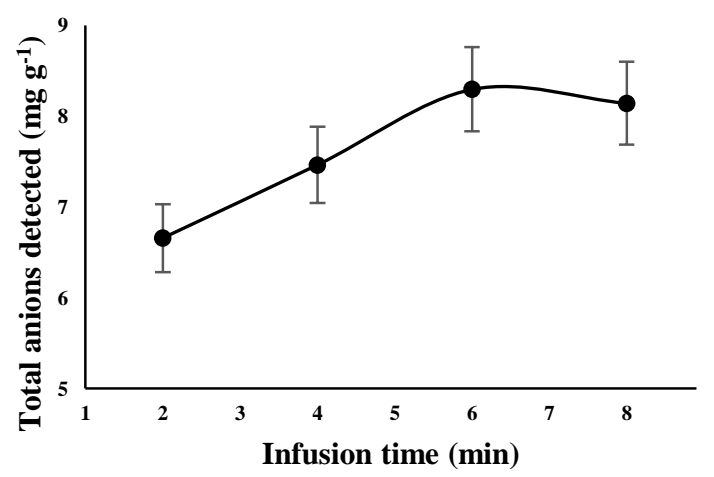

Figure 2. The influence of brewing time of tea bags on total anion content in the infusions. 


\begin{tabular}{llllllll}
\hline \multirow{2}{*}{ Sample } & \multicolumn{7}{c}{ Inorganic anion content $\left(\mathrm{mg} \mathrm{g}^{-1}\right)$} \\
\cline { 2 - 8 } & Fluoride & Chloride & Nitrite & Bromide & Nitrate & Phosphate & Sulphate \\
\hline Black tea & & & & & & \\
No.1 & $2.39 \pm 0.03$ & $1.36 \pm 0.03$ & < LOQ & $<$ LOQ & $0.11 \pm 0.01$ & $3.25 \pm 0.03$ & $1.12 \pm 0.01$ \\
No.2 & $2.43 \pm 0.02$ & $0.85 \pm 0.01$ & < LOQ & $<$ LOQ & $0.10 \pm 0.02$ & $3.63 \pm 0.02$ & $1.16 \pm 0.02$ \\
No.3 & $2.38 \pm 0.03$ & $1.17 \pm 0.01$ & < LOQ & $<$ LOQ & $0.13 \pm 0.02$ & $4.32 \pm 0.03$ & $1.22 \pm 0.01$ \\
Green tea & & & & & & & \\
No.1 & $1.43 \pm 0.03$ & $0.93 \pm 0.01$ & $<$ LOQ & $<$ LOQ & $0.09 \pm 0.01$ & $4.45 \pm 0.11$ & $0.63 \pm 0.02$ \\
No.2 & $1.20 \pm 0.01$ & $0.99 \pm 0.02$ & $<$ LOQ & $<$ LOQ & $0.11 \pm 0.01$ & $3.97 \pm 0.10$ & $0.47 \pm 0.01$ \\
No.3 & $1.59 \pm 0.02$ & $1.42 \pm 0.02$ & $<$ LOQ & $<$ LOQ & $0.12 \pm 0.01$ & $5.60 \pm 0.14$ & $0.89 \pm 0.02$ \\
White tea & & & & & & & \\
No.1 & $1.83 \pm 0.10$ & $0.45 \pm 0.02$ & $<$ LOQ & $<$ LOQ & $0.09 \pm 0.01$ & $3.80 \pm 0.34$ & $0.67 \pm 0.01$ \\
No.2 & $0.58 \pm 0.03$ & $0.20 \pm 0.01$ & < LOQ & $<$ LOQ & $0.11 \pm 0.02$ & $1.17 \pm 0.06$ & $0.56 \pm 0.01$ \\
\hline
\end{tabular}
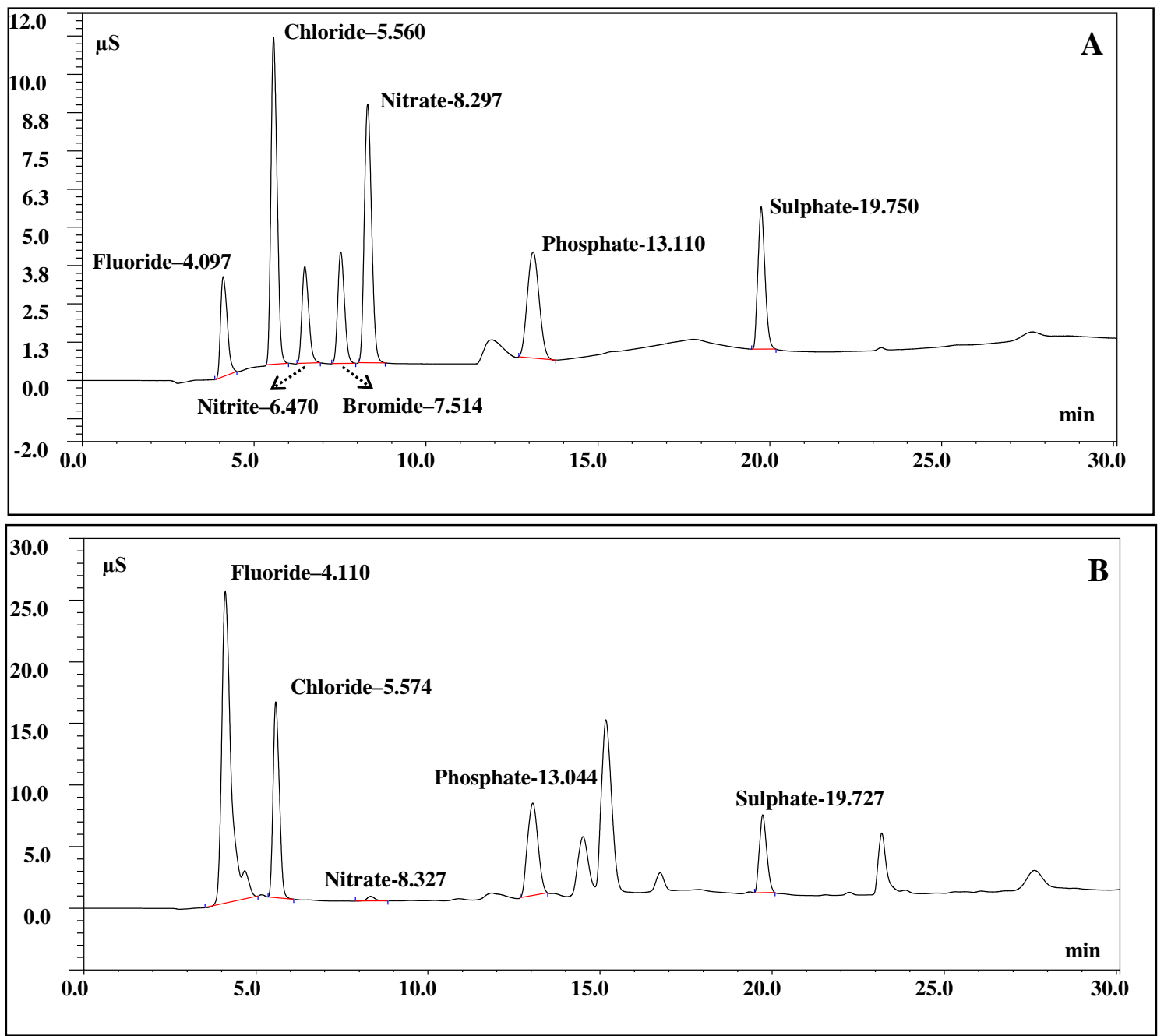

Figure 3. The representative chromatograms of (A) a calibration standard and (B) a black tea bag infusion.

Quantification of anionic amounts present in the set of tea bag samples studied showed variations for all anions: fluoride (ranging from 0.58 to $2.43 \mathrm{mg} \mathrm{g}^{-1}$ ), chloride (ranging from 0.20 to $1.42 \mathrm{mg} \mathrm{g}^{-1}$ ), nitrate (ranging from 0.09 to $0.13 \mathrm{mg} \mathrm{g}^{-1}$ ), phosphate (ranging from 1.17 to $5.60 \mathrm{mg} \mathrm{g}^{-1}$ ), and sulphate (ranging from 0.47 to $1.22 \mathrm{mg} \mathrm{g}^{-1}$ ). The set of black and green tea bag samples were relatively homogeneous compared to the white tea bag samples in terms of the determined inorganic anions. However, 
significant variations were observed in the white tea samples set, especially in terms of fluoride, chloride, and phosphate amounts.

When the amount of inorganic anions in tea types were compared, the amount of fluoride present in the samples decreases in the order black > green > white and the amount of phosphate present in the samples decreases in the order green $>$ black $>$ white. While the highest sulphate content was obtained in black tea samples, there was no significant variation in sulphate content in white and green tea samples analyzed. On the other hand, the lowest amount of chloride was determined in white tea samples and no important variations were observed in black and green tea samples in terms of chloride contents. Finally, approximately the same amount of nitrate was detected in all the tea samples examined.

Average amounts of inorganic anions for tea types obtained from present study were compared with several results available in the literature (Table 5). Table 5 indicated that some of the results obtained for the inorganic anion contents of tea samples were in agreement with the values obtained by earlier workers. On the other hand, there were some significant variances in anion contents of the samples between the present work and the literature data. This was attributed to the leaves harvesting, processing, and blending policies of the manufacturers and the origin of the soil in which the tea samples were grown.

Table 5. Comparison of the results obtained with previous data available in the literature

\begin{tabular}{|c|c|c|c|c|c|c|c|c|c|}
\hline \multirow[t]{2}{*}{ Work } & \multirow{2}{*}{$\begin{array}{l}\text { Brewing } \\
\text { time (min) }\end{array}$} & \multirow{2}{*}{$\begin{array}{l}\text { Tea } \\
\text { type }\end{array}$} & \multicolumn{7}{|c|}{ Inorganic anion content (average results of the analyzed samples, $\mathrm{mg} \mathrm{g}^{-1}$ ) } \\
\hline & & & Fluoride & Chloride & Nitrite & Bromide & Nitrate & Phosphate & Sulphate \\
\hline \multirow[t]{3}{*}{ This work } & 6 & Black & 2.40 & 1.12 & - & - & 0.11 & 3.73 & 1.17 \\
\hline & & Green & 1.41 & 1.11 & - & - & 0.11 & 4.67 & 0.66 \\
\hline & & White & 1.21 & 0.32 & - & - & 0.10 & 2.49 & 0.61 \\
\hline $\begin{array}{l}\text { Kumar et al., } \\
2008\end{array}$ & 20 & Black & 1.20 & 3.12 & - & 0.04 & 0.34 & 0.08 & 4.20 \\
\hline $\begin{array}{l}\text { Milovanovic et } \\
\text { al., } 2018\end{array}$ & $5-20$ & Green & 1.47 & 0.37 & - & - & 0.18 & 1.92 & 1.28 \\
\hline $\begin{array}{l}\text { Alcázar et al., } \\
2003\end{array}$ & - & Black & - & 0.60 & - & - & - & 2.93 & - \\
\hline $\begin{array}{l}\text { Ding et al., } \\
1997\end{array}$ & 20 & Green & - & 1.78 & - & - & - & 7.88 & 4.58 \\
\hline Michalski, 2006 & $10-20$ & Black & 14.86 & 11.19 & - & - & 6.56 & 23.14 & 34.33 \\
\hline $\begin{array}{l}\text { Balcerzak and } \\
\text { Janiszewska, } \\
2015\end{array}$ & 5 & Black & - & 0.75 & - & - & 0.19 & 2.25 & 2.07 \\
\hline Spiro and Lam, & - & Black & 0.06 & 0.90 & - & - & - & 1.18 & 1.45 \\
\hline 1995 & & Green & 0.08 & 0.53 & - & - & - & 0.90 & 2.13 \\
\hline
\end{tabular}

\section{Conclusion}

In present study, ion chromatography technique was used to analyze seven inorganic anions - fluoride, chloride, nitrite, bromide, nitrate, phosphate, and sulphate in commercially available black, green, and white tea bag samples. Tea infusions were prepared traditionally by pouring the tea bags with $200 \mathrm{~mL}$ of boiling ultra-pure water. The optimum brewing time was determined as 6 minutes. Among inorganic anions, five of them were detected quantitatively in the tea infusions. The nitrite and bromide amount in all the samples were well below the quantification limit of the method. The 
method followed would be very useful for practical analysis of inorganic anions in tea infusions without any interferences and the results obtained from the study could contribute to the knowledge of inorganic anions in tea infusions that could be beneficial in human diet.

\section{References}

Alcázar, A., Fernández-Cáceres, P. L., Martín, M. J., Pablos, F., and González, A. G. 2003. "Ion chromatographic determination of some organic acids, chloride and phosphate in coffee and tea", Talanta, 61(2), 95-101.

Balcerzak, M., and Janiszewska, J. 2015. "Determination of common inorganic anions in tea samples by ion chromatography", Acta Alimentaria, 44(3), 365-373.

Ding, M. Y., Chen, P. R., and Luo, G. A. 1997. "Simultaneous determination of organic acids and inorganic anions in tea by ion chromatography", Journal of Chromatography A, 764(2), 341-345.

Jagadish, R., and Shanmugaselvan, V. A. 2018. "Quantification of Inorganic Anions in Tea ( Camellia Sinensis (L) O. Kuntze) Tissues and Soil Using Ion Chromatography Coupled with Conductivity Detector", Communications in Soil Science and Plant Analysis, 49(8), 875-888.

Kumar, S. D., Narayan, G., and Hassarajani, S. 2008. "Determination of anionic minerals in black and kombucha tea using ion chromatography", Food Chemistry, 111(3), 784-788.

Ma, L., Shi, Y., Ruan, J., and Han, W. 2002. "Status of Fluorine in the Soils of Tea Gardens in Brick Tea Areas of Hunan, Hubei Provinces and Its Affecting Factors", Journal Tea Science, 22, 34-38.
Michalski, R. 2006. "Simultaneous determination of common inorganic anions in black and herbal tea by suppressed ion chromatography", Journal of Food Quality, 29(6), 607-616.

Milovanovic, Z., Popovic, S., Pantelic, A., Milinkov, J., Milosevic, D., Petrovic, V., and Vidovic, M. 2018. "Determination of inorganic anions in herbal tea infusions using ion chromatography", Matica Srpska Journal for Natural Sciences, 134, 89-99.

Minca, I., Bajenaru, I., Guran, C., Maria Josceanu, A., and Daniela Isopescu, R. 2015. "Validation of an Ion Chromatographic Method for Determination of Anions in Tea Infusions", Revista de Chimie (Bucharest), 66(6), 759-765.

Mincă, I., Josceanu, A. M., Isopescu, R. D., and Guran, C. 2013. "Determination of ionic species in tea infusions by ion chromatography", UPB Scientific Bulletin, Series B: Chemistry and Materials Science, 75(3), 65-78.

Mondal, T. K., Bhattacharya, A., Laxmikumaran, M., and Ahuja, P. S. 2004. "Recent advances of tea (Camellia sinensis) biotechnology", Plant Cell, Tissue and Organ Culture, 76, 195-254.

Q2B Validation of Analytical Procedures: Methodology| FDA. (1997).

Spiro, M., and Lam, P. L. L. 1995. "Kinetics and equilibria of tea infusion-Part 12. Equilibrium and kinetic study of mineral ion extraction from black Assam Bukial and green Chun Mee teas", Food Chemistry, 54(4), 393396.

Yashin, A. Y., Nemzer, B. V., Combet, E., and Yashin, Y. I. 2015. "Determination of the chemical composition of tea by chromatographic methods: a review", Journal of Food Research, 4(3), 56-87. 